\title{
Corpus in Translation Classroom: A Case Study of Translating Economic Terms
}

\author{
Alexandra G. Anisimova ${ }^{1}$ Dr. sc.; Olga D. Vishnyakova ${ }^{2}$ Dr. sc. \\ Lomonosov Moscow State University, Russia ${ }^{1}$ \\ Lomonosov Moscow State University, Russian State University for the Humanities, Russia ${ }^{2}$ \\ anissimova@list.ru'; ol-vish@mail.ru²
}

\begin{abstract}
The article deals with the role of corpus in translation and translation studies. The paper focuses on different aspects which should be taken into consideration when compiling a representative corpus. The researchers focus on the role the corpus of professional texts plays when choosing translation equivalents for terms, including just created and not yet registered in terminological dictionaries. The aim of the research is to elaborate the approach to the use of corpus material in the course of translation in specialized and professional fields, with particular attention to some aspects of translation competence development. The analysis based on the comparative, definitional and contextual methods proved that parallel text corpora provide professional experts, as well as students of translation, with reliable knowledge of linguistic units functioning and semantic meaning actualization within certain contexts in the Language for Specific Purposes (LSP) domain. The studies have shown that a comparative statistical analysis of a corpus of professional texts might be recommended when looking for an adequate equivalent for a term. The scope of application of the methodology suggested is not confined to certain terminological systems or fields of knowledge. The translation competence development that includes compiling text corpora and making adequate choices by students dealing with appropriate instructions on the part of the teacher, as the task concerns with high level of knowledge acquisition as refers to both linguistic and translation expertise.
\end{abstract}

Keywords: university education, text corpus, translation equivalent, translation competence, Language for Specific Purposes, interdisciplinary.

\section{Introduction}

While doing research in the field of translation one should precede from the premise that different demands of the communicative sphere, where it is used, serve to determine approaches and methods of translation competence development issues. For example, based on the thesis of the significant cognitive dimensions interaction, which includes knowledge, regulatory and problem-solving skills, situation awareness, as well as self-concept realization and psychophysiological traits, the process of translation is understood as a set of complex behaviours, which aims to solve problems of communication, where the use of at least two (spoken, written or signed) languages is manifested (Martin, 2014, 11). Otherwise stated, the problem of conveying a similar meaning in a different language tends to be multi-fold and comprises a number of aspects as referred to translation competence development. Things become further complicated as the information flow seems to be endless and increasing in its complexity and amount. With the advent of the Internet technology, this process has become even more intensive and barely manageable. At the same time, it was precisely with the emergence of new opportunities that the technologies and methods to facilitate and optimize the process of translation as well as to make it more effective have appeared. One of these approaches is concerned with the use of corpora for translation needs, including translation competence development in the course of learning and practical activities implementation.

As is well-known, the results of corpus studies are applied in both learning the language at all levels and in all its manifestations (Bowker, 1998; Dash, Ramamoorthy, 2019; Fligelstone, 1993; McEnery, Wilson, 2008; Sinclair, 1991), as well as in performing various operations with the language, one of the most important and the most difficult among which is translation, both regarding particular methods and techniques of elaboration (Castagnoli, 2012; Musacchio, Palumbo, 2010; Salkie, 2002), as well as in terms of the general concept of translation, with special reference to translation competence issues (Martin, 2014; Pietrzak, 2015; Xiao, Hu, 2015; Zanettin, 2014) and its role in the cultural, intercultural and cross-cultural awareness development, including its cognitive and conceptual basis investigation (Katan, 2009; Liddicoat, 2015; Raitskaya, Tikhonova, 2019; Snell-Hornby, Jettmarová, Kaindl, 1997; Schwieter, Ferreira, 2020). 
The aim of the research is to elaborate the approach to the use of corpus material in the course of translation in specialized and professional fields, with particular attention to some aspects of translation competence development.

\section{Methodology}

The processes of study and creation of text corpora that belong to certain specialized or professional orientation areas, including their specific linguistic features (Gálová, 2007; Ressurrecció, Piorno, GarcíaIzquierdo, 2008), can be considered the most significant tasks within this framework. Experts state that corpus-based approaches are based on cross-linguistic isomorphisms and anisomorphisms, as well as monolingual, bilingual and multilingual corpora data, which are used to validate both corpus-driven and corpus-based methodologies (Vîlceanu, 2019, 1482). It should be mentioned that as an object of the research, a corpus of texts is a complex multi-level dynamic system. Corpus linguistics focuses on linguistic interactions and references in such systems that arise at the level of a corpus of texts - a separate text opposition, as well as other problems related to the corpus of texts as a linguistic and methodological object.

Thus, the corpus under consideration consists of a finite number of texts, and it is intended to adequately reflect the lexical and grammatical phenomena, typical of the texts in the corresponding language (or sublanguage). Two essential features sampling/ selection and representativeness are of extreme importance in corpus linguistics. The first of these features is the way texts are selected for the corpus; the other determines which extra-corpus reality the corpus reflects (or the compiler wishes to reflect).

Corpus-based research includes the following stages: 1) collection of mono-and multilingual text corpora, coding tools and searching tools; 2) linguistic research itself, language analysis, from an experimental point of view, i.e., one has to identify what words, expressions, grammatical constructions, types of discourse are actually used by native speakers, how often and for what purposes.

Ideally, when translating in a particular field of knowledge, you should create two parallel representative corpora that contain texts in two languages - one in English and the other in Russian, which will provide the translator with relevant and reliable information concerning the functioning of a certain translational equivalent in the professional discourse. For example, while discussing parallel corpora, researchers distinguish between comparable corpus and translation corpus, in which the latter is realized as a large and structured set of translated texts between two languages (Salkie, 2016).

Special attention should be given to the translation of terminological units, most of which are registered in terminological dictionaries. At the same time as far as some newly emerging terms are concerned, one may come across that rare situation, when the unit is not registered in the dictionary or requires its presentation in a new context within a new branch of knowledge and linguo-cultural space (Malyuga, Krouglov, Tomalin, 2018). The other case that deserves particular attention is a term manifestation via means of a number of translation equivalents, for instance, by a lexical equivalent, a loan borrowing and a descriptive translation. Despite the fact that an important property of a term is its semantic stability and unambiguity in a certain field of science or professional area, the dynamics of language development and the multidimensional nature of approaches to scientific analysis may sometimes cause nuances of ambiguity in the course of terminological unit functioning. Thus, one should bear in mind that in all these cases parallel translation corpus, especially based on a situational parameter, can be of great benefit. It should be mentioned in this connection that when choosing an equivalent from the options offered by the dictionary and taking such parameters as frequency of use and breadth of distribution into special consideration, the translator can use the statistical method of studying the corpus of professional texts.

\section{Results and Discussion}

At present, philological comparisons can be made not on individual samples, but on mass-presented texts that are available for computer processing. Moreover, the results of such comparisons can be qualitatively different if the research is carried out within the framework of a certain linguistic approach, which includes the rules for organizing texts into a corpus, the methodology for their analysis, and scientific methodology. It should also be pointed out that corpus linguistics has significantly influenced lexicography. An example is COBUILD dictionaries. Consistently applying the principle of computer processing of real speech materials used in the relevant areas of communication, a fundamentally new type of dictionary was 
designed. The results of corpus-based research were diverse and numerous. The ease of accessing huge and diverse linguistic material via the Internet has led to qualitatively new results.

Due to the fact that there are countless texts in the electronic form which are freely available on the Internet, the largest corpus can be considered the Internet itself (Web Corpus), and the means of access to this corpus are search engines. At the same time, texts on the Internet are chaotic, it is often difficult or impossible to formulate a linguistically interesting query using the search engine; it is impossible to assess the representativeness of the sample based on search results.

For this reason, corpus linguistics uses mono - and multilingual text corpora, which are often annotated with linguistically significant information, such as parts of speech, morphological features, syntactic structure, and semantic interpretation.

The representativeness of the corpus is essential for further discussion. To optimize the search for information, the principle of corpus linguistics comes to the fore - relying on a reference corpus of texts that adequately reflects this type of communication. This corpus helps to solve linguistic difficulties based not on idealized models, but on real speech material that has already been used in this type of communication, analysed in terms of Language for Specific Purposes, which is represented by large arrays and various text formats (Ayuningtyas, 2017; Borucinsky, Čolakovac, 2020), reflects the needs of those for whom the learning of a language is auxiliary to some professional or academic purpose (Widdowson, 1983).

Terms are a crucial part of LSP, including the fields of Economics, Law, Politics and other sciences under consideration. There is no doubt that terms belonging to these fields share many features and undergo similar linguistic processes, which are manifested by a great number of texts such as Internet realizations and vividly shown at the level of native and multilingual corpora (Biel, Sosoni, 2017; Botley, McEnery, Wilson, 2000; Pearson, 1996). The specific feature of translating terms is the need to either build equivalents of foreign terms in the native language, or to choose between several translation options recorded in dictionaries. Dictionaries often present several translation options.

Thus, for example, the legal term grantor has the following meaning - a person who transfers the ownership of property by written instrument. This term has several translation equivalents registered in dictionaries:

grantor:

1) лицо, передающее или представляющее право;

2) лицо, предоставляющее дотацию или субсидию;

3) лицо, дающее разрешение.

However, in the corpus of professional documents - power of attorney, descriptions of court precedents, security certificates, mortgages on mortgage collateral, insurance policies, mortgages on property, counterclaims, purchase/sale/gift agreements - the numerical composition of which can be considered representative (over 900,000 words), experts use the term доверитель:

"Know all men by these present that XXX (Cyprus) Limited, a company registered under the laws of Cyprus, under registration number 000, having its registered address at ... (hereinafter called "the Grantor") has made, constituted and appointed and does hereby constitute and appoint Mr. XXX to be the Grantor's lawful Attorney..."

"Настоящим документом все заинтересованные лица уведомляются о том, что компания "XXX (Сайпрус) Лимитед”, зарегистрированная по законодательству Кипра под регистрационным номером 000, с зарегистрированным местонахождением ... (в дальнейшем именуемая “Доверитель”), приняла решение о назначении и наделении полномочиями и настоящим назначает XXX законным Поверенным Доверителя...”

It should be pointed out that the case described above when dictionaries do not register the equivalent which is recurrent in professional communication is quite rare. The most frequent case is the presence in the dictionary (English-Russian Dictionary..., 2020) of two or three translation equivalents of the term, namely, a loan borrowing, a lexical equivalent and a descriptive translation:

aval - аваль, гарантия по векселю;

beneficiary - бенефициар, наследник по завещанию; лицо, в пользу которого действует попечитель; 
bonus - бонус, добавочный дивиденд, премия;

overdraft - овердрафт, кредит по текущему счету.

Such examples are numerous, particularly in the economic terminology. This phenomenon can be accounted for by extralinguistic factors: the globalization of political and economic processes, and, consequently, the information exchange and cooperation in these areas.

Based on such parameters as frequency of use and breadth of distribution, the translator can easily make a choice. As an example, here is a comparative statistical analysis of translating several economic terms using the method of corpus research.

The first step is to create a representative corpus of professional texts based on the methods developed in corpus linguistics. In our case, the corpus is made up of the most authoritative and professional websites:

www.bankir.ru;

www.debit-credit.ru/law-letters;

www.gov.spb.ru/admin.;

www.i-tender.ru;

www.banki.ru;

www.mmbank.ru;

www.sbr.ru;

www.vbank.ru;

www.alfabank.ru;

www.rs.ru;

www.vtb.ru;

www.russbank.ru.

The corpus contains over 3.5 million words, which makes it fairly representative. The analysis has shown the following:

1) loan borrowing is used much more often than the descriptive translation:

овердрафт_(7863); кредит по текущему счету (1684);

бенефициар (3402); лицо, в пользу которого действует попечитель (362);

2) the use of descriptive translation of the term and a loan borrowing is numerically approximately the same:

авизо - (3814); уведомительное письмо - (3821);

3) the existing lexical equivalent is used more often than the loan borrowing or descriptive translation:

баланс - (2430); сальдо - (8390); остаток по счетам - (964);

4) the use of loan borrowing in quotation marks is accompanied by an explanation of the metalanguage of the Bank:

"due diligence" - as a procedure of forming an objective opinion ..... (www.financiallawyer.ru);

"due diligence" - providing due diligence in the process of formation of objective representation about objects ..... (aventa.ru);

"due diligence" - collection, processing and analysis of various information (taxhelp.ru).

At the same time, it should be borne in mind that in the course of teaching, corpus analysis should be used in integrative complex with other methods and techniques applied in the translation process and discussed in the domain of Translation studies, as well as in the course of language learning in the broader sense of the word. H.G. Widdowson, an outstanding UK linguist and methodologist, mentioned that, on the one hand, the analysis of language on the basis of corpus studies has provided linguists with new information as refers to language use and its patterns, although, on the other hand, the parameters and criteria on which the description of language is based in computational corpora analysis should not be necessarily the same as those for the purposes of learning, as for the sake of learning they need to be interpreted to suit pedagogical considerations (Widdowson, 1992, 336). Otherwise stated, a translator's activities, which concern corpora studies, should be based on a high level of expertise, linguistic and 
cultural competence, while students doing translation need to follow careful instructions of the teacher on their way to autonomous learning for using and compiling corpora.

\section{Conclusions}

Thus, to conclude: the use of mono - and multilingual text corpora in translation helps to optimize the search for information, thus identifying the most preferable versions as referred to various communicative spheres, including LSP. Corpus data facilitates the choice of language units by presenting them in particular contexts, both linguistic and linguo-cultural. Thus, in the course of corpus analysis one should accumulate new linguistic information as well as acquire new knowledge in the domain of meaning and functioning of language units and their equivalents in other languages, with special reference to his/her cognitive and conceptual basis extension and development.

The analysis of the corpus of professional texts greatly facilitates the task of both the translator and the lexicographer, indicating statistically more frequently used translation equivalent of the term. In the course of translation competence development, it would be advisable for students to compile their own corpus of texts to choose between two or more translation equivalents of terms registered in dictionaries. Apart from corpus linguistic material, a number of other factors should be taken into consideration, for example, comparative statistical analysis of professional text corpus seems to be appropriate in terms of searching for adequate equivalents for the terms in question, as well as comparative, definitional and contextual methods that are included in the complex methodological approach to the phenomena under consideration. As has been shown in the course of the investigation, the scope of the method application is relevant for the whole area of LSP studies and research.

Text corpora aid to solve problems that occur in the course of real speech communication, by providing learners and professional translators with reliable information as referred to functioning a certain translational equivalent within the domain of academic or professional discourse, which is especially important in the case of interdisciplinary terms (for example, when used in the areas of economics, law or sociology), as well as newly created terms that may not be registered or, vice versa, be accompanied by a number of equivalent versions in dictionaries and other reference materials.

The use of parallel representative corpora that contain texts in two or more languages not only facilitates the process of translation, but also provides students with linguistic knowledge and skills, as well as helps to extend their abilities as referred to translation, comparative studies and intercultural competence development in the course of learning. Parallel text corpora as a universal set of situational representations, subject to comparison, are considered practically significant in terms of quick access to linguistic meaning in context and from the point of view of saving search and language efforts, which is important in terms of heuristic approach to translation.

\section{Bibliography}

1. Ayuningtyas P. (2017). Using authentic materials in the ESP classroom. In Proceedings of the Conference on Language and Language Teaching, 107-113. Retrieved from https://semnas.untidar.ac.id/wp-content/uploads/2018/02/page-107-113-pratika.pdf.

2. Biel L., Sosoni V. (2017). The translation of economics and the economics of translation. Perspectives, 25(3), 351-361. doi: 10.1080/0907676X.2017.1313281

3. Borucinsky M., Čolakovac J.J. (2020). Promoting authenticity in the ESP classroom: The impact of ICT and use of authentic materials on student motivation. In T.V. Petkova, V.S. Chukov (Eds.), The International e-Conference on Studies in Humanities and Social Sciences, 5. Belgrade: Center for Open Access in Science, 32-44. doi: 10.32591/coas.e-conf.05.03031b

4. Botley S., McEnery A., Wilson A. (Eds.). (2000). Multilingual Corpora: Teaching and Research. Amsterdam: Rodopi.

5. Bowker L. (1998). Using Specialized Monolingual Native-Language Corpora as a Translation Resource: A Pilot Study. Meta, 43(4), 631-651. doi: 10.7202/002134ar

6. Castagnoli S. (2012). Regularities and Variations in Learner Translation: A corpus-based Study of Conjunctive Explication. The Interpreter and translator trainer, 6(1), 136-137

7. Dash N.S., Ramamoorthy L. (2019). Corpus as a Primary Resource for ELT. In Utility and Application of Language Corpora. Singapore: Springer, 91-103. doi: 10.1007/978-981-13-1801-6 
8. English-Russian Dictionary of Law. (2020). Retrieved from https://law_en_ru.academic.ru

9. Fligelstone S. (1993). Some Reflections on Teaching, from a Corpus Linguistics Perspective. ICAME Journal 17, 97-109.

10. Gálová D. (Ed.). (2007). Languages for Specific Purposes: Searching for Common Solutions. Cambridge Scholars Publishing.

11. Katan D. (2009). Translation as intercultural communication. In M. Baker (Ed.) Translation Studies. London \& New York: Routledge, 74-92.

12. Liddicoat A.J. (2015). Intercultural mediation, intercultural communication and translation. Perspectives Studies in Translation Theory and Practice, 24(3), 354-364. doi: 10.1080/0907676X.2014.980279

13. Malyuga E.N., Krouglov A., Tomalin B. (2018). Linguo-cultural competence as a cornerstone of translators' performance in the domain of intercultural business communication. XLinguae, 11(2), 566-582. doi: 10.18355/XL.2018.11.02.46

14. Martin R.M. (2014). Situating Translation Expertise: A Review with a Sketch of a Construct. In S. Schwieter, A. Ferreira (Eds.), The Development of Translation Competence: Theories and Methodologies from Psycholinguistics and Cognitive Science. Cambridge Scholars Publishing, 2-56.

15. McEnery T., Wilson A. (2008). Teaching and Language Corpora (TALC). ReCALL 9(1), 5-14. doi: $10.1017 / \mathrm{S} 0958344000004572$

16. Musacchio M.T., Palumbo G. (2010). Following Norms, Taking Risks: A Study of the Use of Connectives in a Corpus of Translated Economics Articles in Italian. In C. Heine, J. Engberg (Eds.), Reconceptualizing LSP: Online proceedings of the XVII European LSP Symposium 2009. Aarhus, Denmark: Aarhus School of Business, Aarhus University. Retrieved from https://www.asb.dk/fileadmin/www.asb.dk/isek/musacchio_palumbo.pdf

17. Pearson J. (1996). Teaching Terminology using Electronic Resources. In S. Botley, J. Glass, T. McEnery, A. Wilson (Ed.), Proceedings of teaching and Language Corpora. UCREL technical papers,9. Lancaster: UCREL, 203-216.

18. Pietrzak P. (2015). Translation competence. In Ł. Bogucki, S. Góźdź-Roszkowski, P. Stalmaszczyk (Eds), Ways to translation. Łódź-Kraków: Łódź University Press \& Jagiellonian University Press, 317-338. Retrieved from https://www.researchgate.net/publication/330134904_Translation_competence.pdf

19. Raitskaya L., Tikhonova E. (2019). A University Course of Intercultural Communication: Fostering Students' Skills and Competence. In V. Dislere (Ed.), The Proceedings of the International Scientific Conference Rural Environment. Education. Personality (REEP), 12. Jelgava: Latvia University of Life Sciences and Technologies, 152-157. Retrieved from doi: 10.22616/REEP.2019.019

20. Ressurrecció M.V., Piorno P.E., García-Izquierdo E. (2008). The Acquisition of Translation Competence through Textual Genre. Translation Journal, 12(4). Retrieved from http://translationjournal.net/journal/46competence.htm

21. Salkie R. (2002). Two types of translation equivalence. In B. Altenberg, S. Granger (Eds.), Lexis in contrast. Amsterdam: John Benjamins, 51-71.

22. Salkie R. (2016). Using parallel corpora in translation. Retrieved from https://www.llas.ac.uk/resources/gpg/1444

23. Schwieter J., Ferreira A. (Eds.). (2020). The Handbook of Translation and Cognition. Wiley Blackwell.

24. Sinclair J. (1991). Corpus, Concordance, Collocation. Oxford: Oxford University Press.

25. Snell-Hornby M., Jettmarová Z., Kaindl K. (Eds.). (1997). Translation as Intercultural Communication: selected papers from EST congress - Prague 1995. Amsterdam, Philadelphia: John Benjamins Publishing Company.

26. Vîlceanu T. (2019). Learner Corpus-Driven Approach to Quality Assurance in Translation. In E. Soare, C. Langa (Eds.). the European Proceedings of Social \& Behavioural Sciences (EpSBS), 67, EduWorld2018. Pilesti, Romania: Future Academy, 1482-1487. doi: 10.15405/epsbs.2019.08.03.182

27. Widdowson H.G. (1983). Learning purpose and language use. Oxford: Oxford University Press.

28. Widdowson H.G. (1992). ELT and EL Teachers: matters arising. ELT Journal, 46(4), 333-339. doi: $10.1093 / \mathrm{elt} / 46.4 .333$

29. Xiao R., Hu X. (2015). Corpus-Based Translation Studies: An Evolving Paradigm. In Corpus-Based Studies of Translational Chinese in English-Chinese Translation. Shanghai: Jiao Tong University Press and Springer-Verlag Berlin Heidelberg. 9-20. doi: 10.1007/978-3-642-41363-6_2

30. Zanettin F. (2014). Corpora in Translation. In J. House (Ed.), Translation: A Multidisciplinary Approach. Palgrave Macmillan, 178-199. doi: 10.1057/9781137025487_10 